Mexican Journal of Biotechnology 2020, 5(2):120-134

Journal homepage:www.mexjbiotechnol.com

ISSN:2448-6590

\title{
Genetic structure of Platanus mexicana var. mexicana (Platanaceae) in southern Mexico
}

\section{Estructura genética de Platanus mexicana var. mexicana (Platanaceae) en el sur de México}

Dulce María Galván-Hernández ${ }^{1}$, Pablo Octavio-Aguilar ${ }^{1}$, Oscar CarmonaHernández², Hugo Asselin ${ }^{3}$ \& José Armando Lozada-García ${ }^{4 *}$

1 Centro de Investigaciones Biológicas, Universidad Autónoma del Estado de Hidalgo, Carretera Pachuca-Tulancingo Km 4.5 Col. Carboneras, C.P. 42184, Mineral de la Reforma, Hidalgo, Mexico.

2 Facultad de Ciencias Agrícolas Xalapa, Universidad Veracruzana. Circuito Universitario Gonzalo Aguirre Beltrán s/n, Zona Universitaria, C.P. 91000, Xalapa, Veracruz, Mexico.

${ }^{3}$ School of Indigenous Studies, Université du Québec en Abitibi-Témiscamingue, 445 boulevard de l'Université, Rouyn-Noranda, Québec, J9X 5E4, Canada.

${ }^{4}$ Facultad de Biología, Universidad Veracruzana, Circuito Gonzalo Aguirre Beltrán s/n, Zona Universitaria, C. P. 91090, Xalapa, Veracruz, Mexico.

${ }^{*}$ Corresponding author

E-mail address: alozada@uv.mx (J. A. Lozada-García)

Article history:

Received: 9 January 2020 / Received in revised form: 21 April 2020 / Accepted: 24 April 2020 / Published online: 4 May 2020.

https://doi.org/10.29267/mxib.2020.5.2.120

\begin{abstract}
Platanus mexicana is a typical species of the tropical cloud forest with a complex biogeographical history. High adaptive radiation and interspecific hybridization have been reported for this species, leading to high genetic variability and low differentiation. However, previous studies have shown that populations in the southern part of the species' distribution in Mexico show different patterns. Therefore, this research aimed at characterizing the genetic structure of three Platanus mexicana populations in southern Mexico. The results revealed significant differences between the populations in Oaxaca, Veracruz and Chiapas (FST $=0.235 \pm$ 0.08 ), whereas there was evidence of gene flow between the two northwestern populations $(\mathrm{Nm}=1.5)$. Bayesian analysis of allele frequencies showed high selection pressure in Veracruz. Furthermore, the alleles that shifted away from the neutral model were overrepresented in Chiapas. The Oaxaca population had the highest genetic variability values $(\mathrm{He}=0.25 ; \mathrm{P}=68.7)$, whereas the Chiapas
\end{abstract}


population displayed the highest differentiation $(\mathrm{Nei}=0.134)$. Considering the biogeographical history and topographic heterogeneity of the region, the results suggest three differentiation processes: presence of a climate refugium in Oaxaca, allopatry between Veracruz and Oaxaca, and vicariance in Chiapas.

Keywords: Allopatry; Bayesian analysis; Climate refugium; Natural selection; Sycamore; Vicariance.

\section{RESUMEN}

Platanus mexicana es una especie característica del bosque de niebla con una compleja historia biogeográfica. Se ha reportado alta radiación adaptativa e hibridación interespecífica en esta especie, lo cual está asociado con alta variación genética y poca diferenciación. Sin embargo, estudios previos han mostrado diferencias significativas entre las poblaciones al sur de su distribución en México. Por tanto, este trabajo tiene como objetivo caracterizar la estructura genética entre tres poblaciones de esta especie en el sur del país. Los resultados muestran diferencias significativas entre poblaciones de Oaxaca, Veracruz y Chiapas (Fst = $0.235 \pm 0.08$ ) aunque existe evidencia de flujo genético entre las dos poblaciones del noroeste $(\mathrm{Nm}=1.5)$. El análisis bayesiano de frecuencias alélicas mostró alta presión de selección en Veracruz. Además, los mismos alelos que se alejan del modelo neutral están sobrerrepresentados en Chiapas. La mayor variabilidad genética se encontró en Oaxaca $(\mathrm{He}=0.25, \mathrm{P}=68.7)$ y la población con mayor diferenciación genética fue Chiapas (Nei $=0.134$ ). Considerando la historia biogeográfica y heterogeneidad topológica, los resultados obtenidos sugieren tres procesos de diferenciación: la presencia de un refugio climático en Oaxaca, alopatría entre Veracruz y Oaxaca, y vicarianza en Chiapas con el resto de las poblaciones.

Palabras clave: Alopatría; Análisis bayesiano; Haya; Refugio climático; Selección natural; Vicarianza.

\section{INTRODUCTION}

While the Platanaceae botanical family was abundant and diverse during the Cretaceous and early Tertiary, it is currently represented by a single genus (Platanus) including seven species, five of which are found in North America. Following a dry episode during the Tertiary, the five North American species were segregated into the western (two species) and eastern (three species) parts of the continent, the genus being virtually absent in the center (Nixon \& Poole, 2003). Later on, during the Pleistocene, population decline of some species has been attributed to glaciations, as exemplified by low genetic diversity in Platanus occidentalis (Besnard et al., 2002; Feng et al., 2005). Molecular data suggests that Platanus rzedowskii emerged as an hybrid of $P$. mexicana and $P$. occidentalis favored by the cyclic expansion and reduction of the latter species' distribution range during Pleistocene glaciations (Nixon \& Poole, 2003; Feng et al., 2005; Grimm \& Denk, 2008), which affected gene flow (Hampe \& Jump, 2011).

Different mechanisms can contribute to gene flow in plants, eventually leading to hybridization. Studies with molecular markers have shown a high level of 
hybridization in the genus Platanus; examples of hybrids are $P$. densicoma, $P$. hispanica, and P. x acerifolia (Besnard et al., 2002; Grimm \& Denk, 2008). In addition, horizontal gene flow has been shown to occur between wild populations of $P$. mexicana (var. mexicana and var. interior), P. occidentalis (var. palmeri and var. occidentalis) and P. rzedowskii.

Genetic variability is affected by climate and landscape features, which can combine to create so-called "climate relicts". Mexico is a country with wide variations in topography and physiography, creating different microclimates ideal for speciation (Sosa et al., 2018). Temperate genera such as Carpinus, Clethra, Cornus, Liquidambar, Pinus and Platanus can be found at mid-to-high altitudes in Mexico, the elevation gradient providing a barrier to gene flow with Neotropical species located at lower altitudes (Graham, 1999; Rico, 2019). The biogeographical history of Mexico suggests that mountains might have been climate refugia during the Pleistocene, especially in the Balsas Basin (Luna-Vega, 2008). This region includes the western part of the states of Tlaxcala, Puebla, Oaxaca and Guerrero. To the northwest, it is separated from the Central Plateau by the Trans Mexican Volcanic Belt. To the southeast, it is separated from the High Grijalva Basin by the Sierra de Juárez. To the northeast, it is separated from the Papaloapan Basin by the Sierra Norte de Oaxaca (Fig. 1).

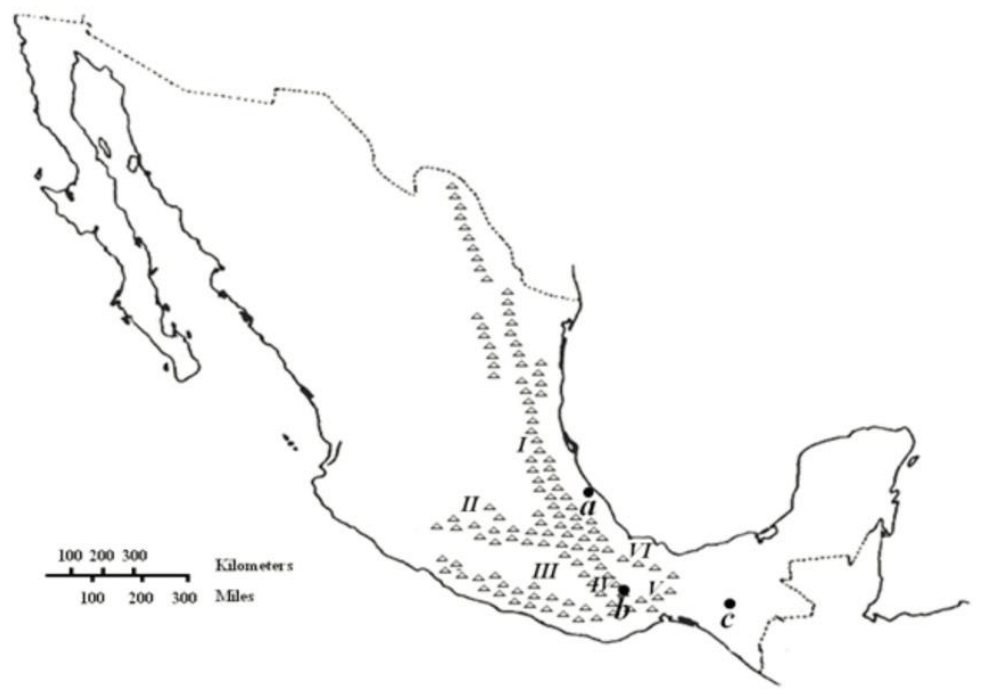

Fig. 1. Main topographic barriers in southern Mexico: I) Sierra Madre Oriental; II) Trans Mexican Volcanic Belt; III) Balsas Basin; IV) Sierra de Juarez; V) Upper Grijalva Basin; VI) Papaloapan Basin. Studied Platanus mexicana var. mexicana populations: a) Colipa, Veracruz; b) San Juan Comaltepec, Oaxaca; c) Ixtapa, Chiapas.

Fig. 1. Principales barreras topográficas en el sur de México: I) Sierra Madre Oriental; II) Faja Volcánica Transversal; III) Cuenca del balsas; IV) Sierra de Juárez; V) Cuenca superior de Grijalva; VI) Cuenca del Papaloapan. Poblaciones de Platanus mexicana var. mexicana estudiadas: a) Colipa, Veracruz; b) San Juan Comaltepec, Oaxaca; c) Ixtapa, Chiapas.

Populations of Platanus mexicana var. interior are present from the southeast of Tamaulipas to the Balsas Basin, through the states of San Luis Potosí, Querétaro and Hidalgo in the Sierra Madre Oriental. P. mexicana var. mexicana is found from 
north of Veracruz (Pánuco) on the coastal side of the Sierra Madre Oriental, south to Guatemala, through the states of Hidalgo, Puebla and Oaxaca (Denk et al., 2012). The distinction between the interior and mexicana varieties is still controversial. While Denk et al. (2012) suggest they belong to a unique species with high phenotypic plasticity, Nixon \& Poole (2003) argue there is enough morphological distinction to warrant considering them as two different species. Plastid DNA sequencing and nuclear SNP (single nucleotide polymorphism) genotyping data supported the twospecies hypothesis (De Castro et al., 2013).

Adding to the debate, nuclear and chloroplast DNA provided evidence of differentiation between populations of Platanus mexicana var. mexicana from the Balsas Basin in central Mexico and those in Veracruz and Chiapas (Feng et al., 2005). This raises various questions: How important is physiographic diversity for the differentiation of $P$. mexicana var. mexicana populations with high hybridization potential? Can the Balsas Basin be considered a climate refugium for this species? Is it possible to differentiate populations in Veracruz and Chiapas from those in Oaxaca (Balsas Basin) using highly polymorphic multiloci molecular markers such as ISSR (Inter Simple Sequence Repeat)? To answer these questions, a population genetics study was conducted on three $P$. mexicana var. mexicana populations from southern Mexico.

\section{MATERIAL AND METHODS}

\subsection{Plant material}

Leaves of Platanus mexicana var. mexicana (Mexican sycamore) were collected without mechanical damage from 30 randomly selected individuals in each of three wild riparian populations, maintaining a minimum distance of $25 \mathrm{~m}$ between sampled trees to ensure genetic independence. The plant material was dried following the procedure suggested by Chase \& Hills (1991), and stored until analysis. The sampled populations were located in tropical cloud forests in Ixtapa, Chiapas (1234 $\mathrm{m}$ asl; $16^{\circ} 47^{\prime} 17^{\prime \prime} \mathrm{N}$; 95 $95^{\circ}$ '53" W) and San Juan Comaltepec, Oaxaca (900 m asl; $17^{\circ} 19^{\prime} 19^{\prime \prime} \mathrm{N}$; $95^{\circ} 59^{\prime} 5^{\prime \prime} \mathrm{W}$ ), as well as in a transition zone between tropical cloud forests and lowland forests in Colipa, Veracruz (620 m asl; 16 $16^{\circ} 49^{\prime} 24^{\prime \prime} \mathrm{N}$; 96 $96^{\circ} 47^{\prime} 43^{\prime \prime}$ W) (Fig. 1). The studied populations were located $387 \pm 124 \mathrm{~km}$ from each other and were considered independent as the distance of Platanus pollen flux is $2.7 \mathrm{~km}$ (Bricchi et al., 2000). Low genetic structure among riparian $P$. mexicana populations along a $1700-m$ elevation gradient in Veracruz has been explained by transport of pollen and seeds (Galván-Hernández et al., 2015). A small number of migrants is sufficient to alter the genetic structure of the dominant population through genetic drift (Grueva \& Zhelev, 2011).

\subsection{DNA extraction and ISSR amplification.}

DNA extraction was performed following the method of Doyle \& Doyle (1990) with minor modifications. DNA quantity and quality were determined by spectrophotometry at $260 \mathrm{~nm}$ and gel electrophoresis. Ten ISSR UBC (University of British Columbia) primers were selected (Table 1) based on a clear and reproducible banding pattern. ISSR markers were used due to their capacity to evaluate differentiation between and within populations, to estimate homozygotes and 
heterozygotes, as well as to identify alleles associated with different evolutionary forces exclusive of each population (Bornet \& Branchard, 2001; Foll \& Gaggiotti, 2008; Trieu et al., 2016; Wang et al., 2017).

Amplification was performed following the procedure described by Xiao \& Gong (2006) with slight modifications. The total volume of the PCR reaction was $20 \mu \mathrm{L}$ with $10 \mathrm{ng}$ of template, $1 \times\left(\mathrm{NH}_{4}\right)_{2} \mathrm{SO}_{4}$ buffer, $3 \mathrm{mM} \mathrm{MgCl}$, $0.375 \mathrm{mM} \mathrm{dNTPs}, 1 \mu \mathrm{M}$ of each primer, 1 unit of Taq DNA polymerase (Fermentas) and double distilled water. The thermal cycle was as follows: initial denaturation at $94{ }^{\circ} \mathrm{C}$ for 4 minutes, followed by 35 cycles of 30 seconds at $94^{\circ} \mathrm{C}, 45$ seconds at the annealing temperature of each primer $\left(50{ }^{\circ} \mathrm{C}\right.$ for $818,824,827,829 ; 53^{\circ} \mathrm{C}$ for $835,841,845,848,850$ and 857), and 90 seconds at $72{ }^{\circ} \mathrm{C}$; followed by a final extension at $72{ }^{\circ} \mathrm{C}$ for 8 minutes. Amplification products were separated by gel electrophoresis and documented using the Kodak ID 3.5 image analysis software.

Table 1. Primers for the ten ISSR UBC genetic markers selected for this study.

Tabla 1. Iniciadores para los diez marcadores genéticos ISSR UBC seleccionados para este estudio.

\begin{tabular}{ccccc}
\hline Primer & Sequence & $\begin{array}{c}\text { Size Range } \\
\text { (base pairs) }\end{array}$ & Bands & $\begin{array}{c}\text { Polymorphic } \\
\text { bands }\end{array}$ \\
\hline 818 & (CA)8G & $350-1000$ & 12 & 9 \\
824 & (TC)8G & $350-1500$ & 9 & 8 \\
827 & (AC)8G & $400-1400$ & 9 & 8 \\
829 & (TG)8C & $480-1700$ & 7 & 4 \\
835 & (AG)8YC & $180-1400$ & 9 & 7 \\
841 & (GA)8YC & $300-1200$ & 9 & 7 \\
845 & (CT)8RG & $250-1500$ & 12 & 10 \\
848 & (CA)8RG & $300-1500$ & 10 & 9 \\
850 & (GT)8TYC & $300-1500$ & 13 & 11 \\
857 & (AC)8YG & $180-1500$ & 15 & 14 \\
\hline & & Total Bands & $\mathbf{1 0 5}$ & $\mathbf{8 7}$
\end{tabular}

Y: pyrimidine; R: purine.

Y: piridimidina; R: purina

\subsection{Data analysis}

The amplified bands were recorded as 1 (present), 2 (absent) or 0 (non-amplified). Percentage of polymorphic loci (\% P), number of alleles per locus (A), effective number of alleles per locus ( $\mathrm{Ne})$, expected heterozygosity $(\mathrm{He})$ and Shannon index (I) were estimated from the allele frequencies $p$ and $q$ with the adjustment of Lynch \& Milligan (1994) using TFPGA v. 1.3 (Miller, 1997). An AMOVA was performed with GenAIEx v. 6.41 (Peakall \& Smouse, 2006) to determine the partition of genetic variation within and between populations. Genetic distance was estimated using the method of Nei \& Lee (1979) and a UPGMA dendrogram was made using TFPGA v. 1.3 .

Outliers in allele frequencies possibly associated with processes of natural selection were identified using BayeScan v.1.0 (Foll \& Gaggiotti, 2008). The model was iterated 5,000 times with 20 -iteration intervals between samples. The $\log _{10}$ of the 
Bayesian Factor (BF) was considered with substantial $(p=76)$ and strong $(p=90.9)$ cuts on Jeffreys' scale of evidence. BF is the probability that an allele frequency at a specific locus corresponds to an M1 or M2 model (neutral or under selection, respectively); high BF values indicate that the M2 model better fits the data. Jeffreys' criterion is the percentage of iterations in which an allele shifts away from the neutral model (M1).

An additive model with the option of correlated allele frequencies between populations (Falush et al., 2007) was used in the STRUCTURE software to assess the genetic structure of populations. A total of 50,000 MCMC (Markov Chain Monte Carlo) iterations were realized for both elements and 50 runs for each $K$ were evaluated $(K=1$ to $K=10)$. The estimated value of stock $(K)$ was determined by the graphical method $\Delta K$ proposed by Evanno et al. (2005). Finally, gene flow between populations was calculated from the coefficient of genetic differentiation (FST) with the formula $\mathrm{Nm}=(1-\mathrm{FsT}) / 4 \mathrm{Fst}_{\mathrm{ST}}$ (Slatkin \& Barton, 1989), where $\mathrm{Nm}$ is the number of migrants per generation.

\section{RESULTS}

A total of 131 loci were identified on 81 individuals using the ISSR markers; 29 from Chiapas, 23 from Oaxaca and 29 from Veracruz. All genetic variability indices had higher values for Oaxaca compared with Chiapas and Veracruz (Table 2).

Table 2. Genetic variability indices of $P$. mexicana var. mexicana populations in southern Mexico.

Tabla 2. Índices de variabilidad genética entre poblaciones de $P$. mexicana var. mexicana en el sur de México.

\begin{tabular}{lcccccc}
\hline Population & N & A & Ne & He & P & I \\
\hline Chiapas & 29 & 1.649 & 1.365 & 0.225 & 67.176 & 0.340 \\
Oaxaca & 23 & 1.832 & 1.408 & 0.250 & 68.702 & 0.379 \\
Veracruz & 29 & 1.588 & 1.385 & 0.234 & 65.649 & 0.353
\end{tabular}

$\mathrm{N}$ : individuals estimated by TFPGA v. 1.3; A: alleles per locus; Ne: effective number of alleles per locus; He: expected heterozygosity; P: polymorphism; I: Shannon index

$\mathrm{N}$ : Individuos estimados por TFPGA v. 1.3; A: Alelos por locus; Ne: Número de alelos por locus; He: heterozigotos esperados; P: polimorfismo; I: Índice de Shannon

The AMOVA revealed a significant genetic structure $\left(F_{S T}=0.235, p<0.001\right)$, with three times more variation within than among populations (Table 3). The Oaxaca and Veracruz populations were genetically more similar (Fig. 2), significantly different from the Chiapas population as shown by the genetic distance value $(\mathrm{Nei}=0.134)$. 
Table 3. AMOVA of $P$. mexicana var. mexicana populations in Oaxaca, Veracruz and Chiapas.

Tabla 3. AMOVA para poblaciones de $P$. mexicana var. mexicana en Oaxaca, Veracruz y Chiapas.

\begin{tabular}{lccccc}
\hline Source & df & SS & MS & F & $\%$ \\
\hline Among populations & 2 & 349.571 & 174.785 & 5.571 & 24 \\
Within populations & 82 & 1433.747 & 17.485 & 17.485 & 76 \\
Total & 84 & 1783.318 & & 23.056 & 100
\end{tabular}

df: degrees of freedom; SS: sum of squares; MS: mean squares; F: Fisher's estimate; \%: percentage of accumulated variance.

df: grados de libertad; SS: suma de cuadrados; MS: cuadrados medios,: F: Estimados de

Fisher; \%: Porcentaje de variaza acumulada
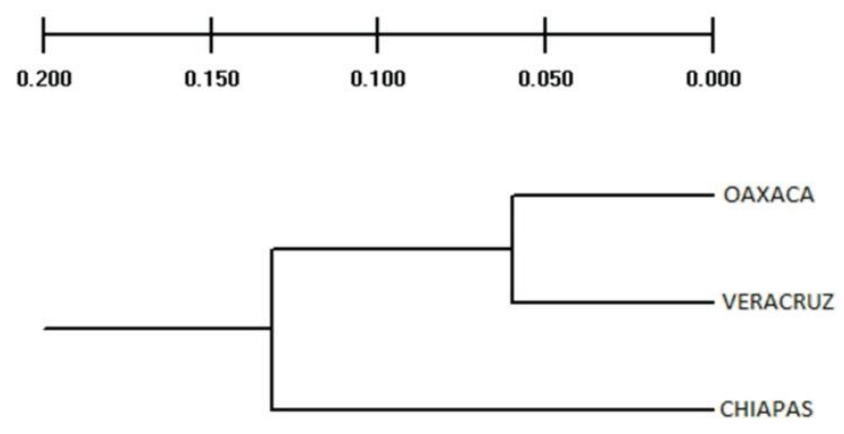

Fig. 2. UPGMA dendrogram based on Nei's genetic distance between P. mexicana var. mexicana populations in Oaxaca, Veracruz and Chiapas.

Fig. 2. Dendrograma UPGMA basado en las distancias genéticas de Nei entre poblaciones de $P$. mexicana var. mexicana en Oaxaca, Veracruz y Chiapas.

The outlier analysis showed that ten loci exceeded Jeffreys' substantial criterion and six loci exceeded the strong criterion (Fig. 3), hence subject to the effects of natural selection. The latter six loci were less frequent in Veracruz $(0.11 \pm 0.13)$, followed by Oaxaca $(0.50 \pm 0.42)$ and Chiapas $(0.70 \pm 0.35)$. The allelic frequencies showed higher genetic difference between populations when considering those 6 loci (FsT = $0.376 \pm 0.05$ ) (Table 4), compared to the general differentiation (Fst $=0.235, p<$ 0.001). Differentiation was lower between the Oaxaca and Veracruz populations, indicating higher gene flow (Table 5). 


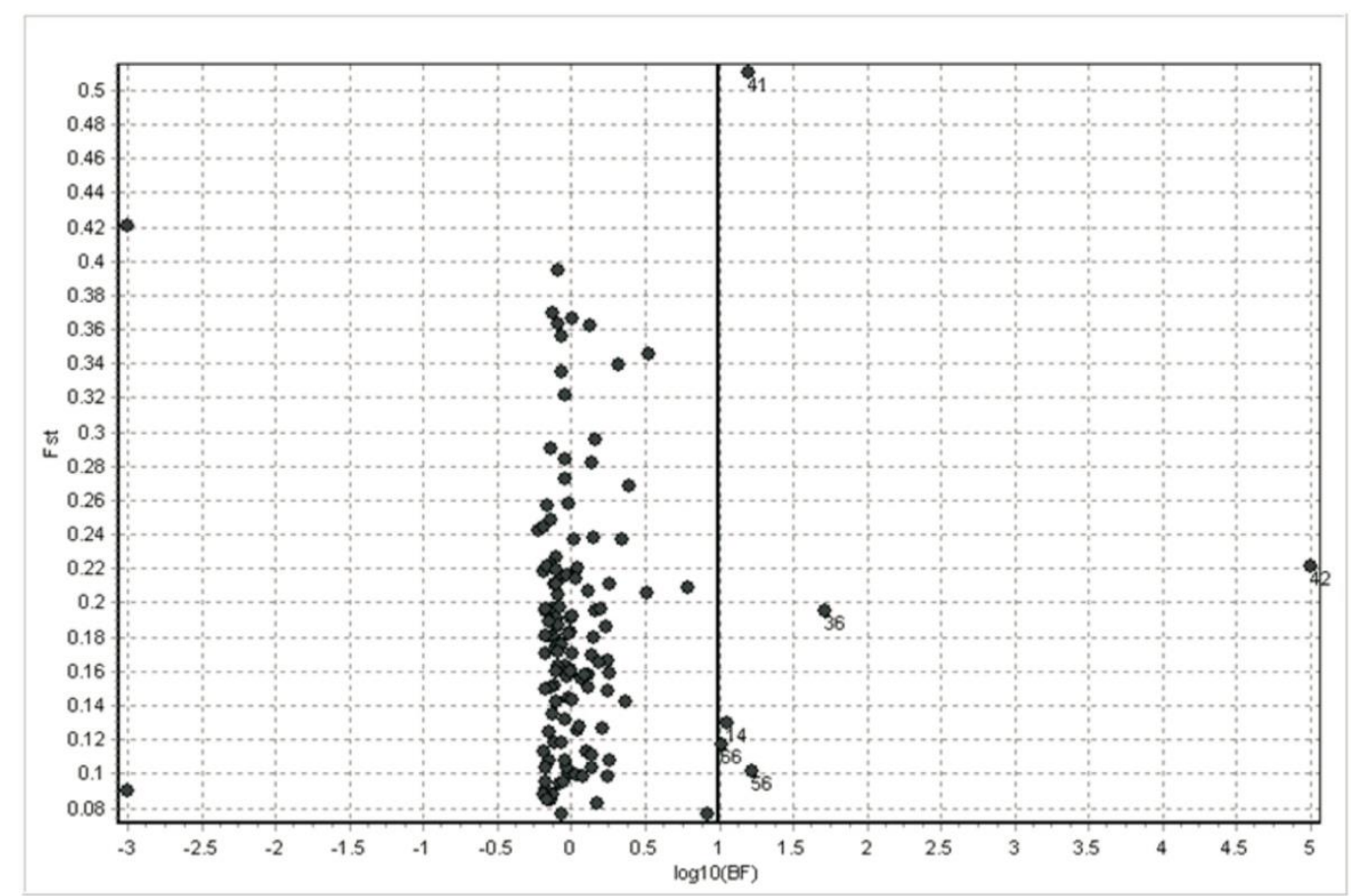

Fig. 3. Bayesian analysis of allelic frequencies for $P$. mexicana var. mexicana populations in southern Mexico. Six loci shifted away from the expected allelic frequencies under a model of natural selection. The cut line corresponds to Jeffreys' strong criterion.

Fig. 3. Análisis Bayesiano de frecuencias alélicas para población de $P$. mexicana var. mexicana en el sur de México. Seis loci se alejan de las frecuencias alélicas esperadas bajo el modelo de selección natural. La línea de corte corresponde al criterio de Jeffreys.

Heterozygosity and the Shannon index were higher in Chiapas for the six loci exceeding Jeffreys' strong criterion ( $\mathrm{He}=0.365 ; \mathrm{I}=0.525)$ than for all loci combined ( $\mathrm{He}=0.225 ; \mathrm{I}=0.340)$, suggesting that selection favored heterozygotes for these loci in Chiapas. To the contrary, the values were lower in Oaxaca when considering only those six loci $(\mathrm{He}=0.231 ; \mathrm{I}=0.369)$ compared to global values $(\mathrm{He}=0.250 ; \mathrm{I}=$ 0.379). The same situation was found in Veracruz $(\mathrm{He}=0.205$ and $\mathrm{I}=0.310$ for the six loci, compared to $\mathrm{He}=0.234$ and $\mathrm{I}=0.353$ globally).

The STRUCTURE analysis showed that the best explanation for population structure was found with $K=3$, hence identifying three groups corresponding to each population. The Oaxaca and Veracruz populations shared allelic variables, and were different from the Chiapas population (Fig. 4). Gene flow was higher between Oaxaca and Veracruz $(\mathrm{Nm}=1.50)$ (Table 5), in line with the results from the UPGMA (Fig. 2). 
Table 4. Populations' allelic frequencies for the loci shifting away from the neutral natural selection model obtained on the Bayesian analysis.

Tabla 4. Frecuencias alélicas de las poblaciones para los loci que se alejan del modelo de selección neutral obtenido en el análisis Bayesiano.

\begin{tabular}{|c|c|c|c|c|c|c|c|}
\hline Loci & Population & FA & $p$ & $\log _{10} B F$ & $\alpha$ & $F_{S T}$ & Jeffreys \\
\hline & Chiapas & 0.9 & & & & & \\
\hline \multirow[t]{3}{*}{12} & Oaxaca & 0 & 0.91878 & 1.0536 & 1.1624 & 0.36874 & 90.9 \\
\hline & Veracruz & 0.2333 & & & & & \\
\hline & Chiapas & 0.8666 & & & & & \\
\hline \multirow[t]{3}{*}{34} & Oaxaca & 1 & 0.98100 & 1.7128 & 1.2741 & 0.39171 & 90.9 \\
\hline & Veracruz & 0.1333 & & & & & \\
\hline & Chiapas & 0.7179 & & & & & \\
\hline \multirow[t]{3}{*}{39} & Oaxaca & 1 & 0.93979 & 1.1933 & 1.1563 & 0.36662 & 90.9 \\
\hline & Veracruz & 0.2333 & & & & & \\
\hline & Chiapas & 0.8666 & & & & & \\
\hline \multirow[t]{3}{*}{40} & Oaxaca & 1 & 1.0000 & 1000.0 & 1.8125 & 0.51110 & 90.9 \\
\hline & Veracruz & 0 & & & & & \\
\hline & Chiapas & 1 & & & & & \\
\hline \multirow[t]{3}{*}{54} & Oaxaca & 0.32 & 0.94379 & 1.2251 & 1.1701 & 0.36898 & 90.9 \\
\hline & Veracruz & 0.1666 & & & & & \\
\hline & Chiapas & 0.1333 & & & & & \\
\hline \multirow[t]{3}{*}{64} & Oaxaca & 0.76 & 0.91298 & 1.0209 & 1.1434 & 0.36385 & 90.9 \\
\hline & Veracruz & 0 & & & & & \\
\hline & Chiapas & 0.7666 & & & & & \\
\hline \multirow[t]{3}{*}{57} & Oaxaca & 0.04 & 0.76875 & 0.52171 & 0.99755 & 0.33520 & 76 \\
\hline & Veracruz & 0 & & & & & \\
\hline & Chiapas & 1 & & & & & \\
\hline \multirow[t]{3}{*}{58} & Oaxaca & 0.32 & 0.86177 & 0.79480 & 1.0658 & 0.34687 & 76 \\
\hline & Veracruz & 0.3666 & & & & & \\
\hline & Chiapas & 0 & & & & & \\
\hline \multirow[t]{3}{*}{112} & Oaxaca & 0.6 & 0.89178 & 0.91594 & 1.1287 & 0.36153 & 76 \\
\hline & Veracruz & 0 & & & & & \\
\hline & Chiapas & 0.7 & & & & & \\
\hline \multirow[t]{2}{*}{117} & Oaxaca & 0 & 0.76335 & 0.50862 & 1.0292 & 0.34260 & 76 \\
\hline & Veracruz & 0 & & & & & \\
\hline
\end{tabular}

FA: allelic frequencies, Fst: fixation index.

FA: Frecuencia alélica; Fst: índice de fijación 


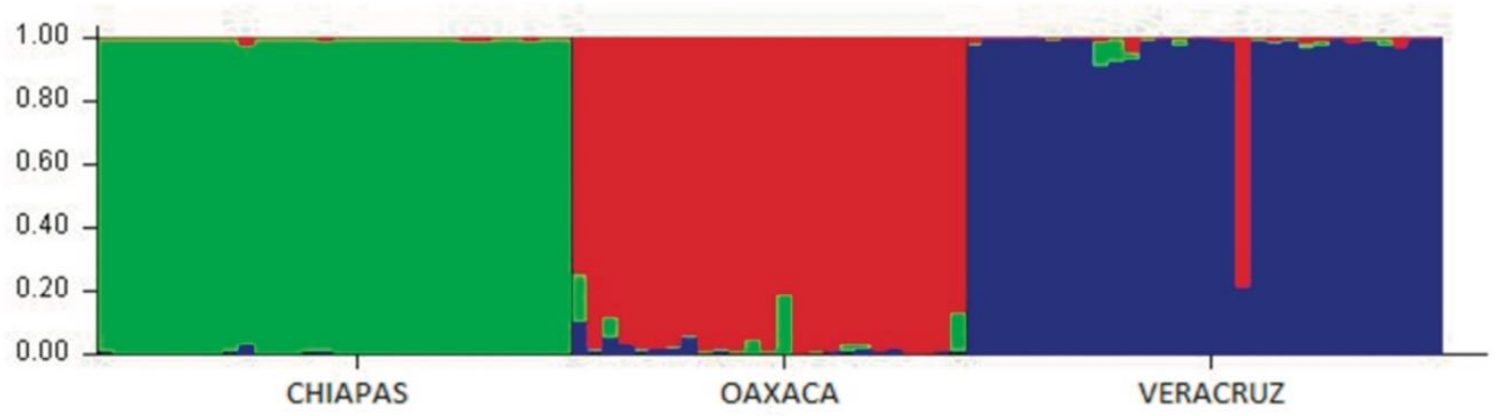

Fig. 4. STRUCTURE analysis $(K=3)$ showing the proportion of shared genetic groups among three populations of $P$. mexicana var. mexicana.

Fig. 4. Análisis de STRUCTURE $(K=3)$ que muestra la proporción de grupos genéticos compartidos entre tres poblaciones de $P$. mexicana var. mexicana.

Table 5. Gene flow estimate between populations of $P$. mexicana var. mexicana in southern Mexico.

Tabla 5. Flujo genético estimado entre poblaciones de $P$. mexicana var. mexicana en el sur de México.

\begin{tabular}{lcc}
\hline Comparison & Fst & Nm \\
\hline Chiapas-Oaxaca & 0.2733 & 0.6647 \\
Chiapas-Veracruz & 0.2901 & 0.6118 \\
Oaxaca-Veracruz & 0.1427 & 1.5019 \\
\hline Fs:
\end{tabular}

Fst: fixation index; Nm: migrants per generation.

Fst: índice de fijación; Nm: migrantes por generación.

\section{DISCUSSION}

The Platanus mexicana var. mexicana population located in Oaxaca had a higher genetic diversity than the other two studied populations, strengthening the assertion that the Balsas Basin might be a climate refugium (Luna-Vega, 2008). Relict populations generally have higher levels of genetic diversity than rare or endemic populations (e.g., Konnert \& Bergman, 1995; Demesure et al., 1996; Soltis et al., 1997; Sinclair et al., 1998; Esselman et al., 2000). Higher gene flow was noted between the Oaxaca and Veracruz populations, possibly explained by higher topographic connectivity compared with the Chiapas population. This suggests that the area between the Oaxaca and Veracruz populations could be an intraspecific hybridization zone. However, heterozygosity and percentage of polymorphic loci were lower in Veracruz than Oaxaca, indicating differentiation despite the hybridization potential. It has been suggested previously that different genotypes can exist in adjacent continental regions (Hewitt, 2011). Hence, despite topographic connectivity, allopatric processes seem to be at play between the Oaxaca and Veracruz populations. Indeed, the STRUCTURE analysis showed that while both populations shared some alleles, most were exclusive. 
Allopatric differentiation processes can occur due to selective pressure increasing differentiation, whether or not there is gene flow between populations (Avise, 2004). The Bayesian model indicated important allele loss in the Veracruz region related with high environmental pressure. The weather in Veracruz ranges from warm to temperate and $P$. mexicana var. mexicana can grow there as low as $70 \mathrm{~m}$ asl, which is well outside the described range for this species. Therefore, even with a gene flow between 1.5 and 4.1 migrants per generation between the alleged Pleistocene refuge (Oaxaca) and allopatric population (Veracruz), migrant alleles are likely eliminated as they do not confer adaptive advantage. Further analysis with co-dominant genetic markers will be necessary to more accurately evaluate the effect of natural selection in the Veracruz region.

The Chiapas population presented greater genetic differentiation compared to the Oaxaca and Veracruz populations, but without significant differences in heterozygosity and polymorphism. The Sierra Norte de Oaxaca is a topographic barrier separating the Oaxaca and Veracruz populations (to the north-west) from the Chiapas population (to the south-east). In the state of Chiapas, there are only a few isolated patches of tropical cloud forest near Cerro Azul (CONABIO, 2010), and the Platanus population sampled at the Ixtapa site is surrounded by tropical vegetation. Geographical discontinuity might thus explain the higher genetic differentiation, but not the apparent allelic richness.

According to the Pleistocene refugia hypothesis, tropical cloud forests were relegated to a few areas at mid-altitude during glaciations (Toledo, 1982; Aide \& Rivera, 1998; Vovides et al., 2004), between too cold conditions at higher altitudes and too dry conditions at lower altitudes (Ramírez-Barahona \& Eguiarte, 2013). Tropical cloud forests expanded again during interglacial periods, this cyclic pattern of contraction and expansion generating a reticulate genetic structure due to successive isolation and reconnection of populations (Comes \& Kadereit, 1998; Edwards et al., 2016). However, the Pleistocene refugia hypothesis has been contested, as some researchers could not find evidence of prolonged drought at low altitudes during glaciations (Colinvaux et al., 2000; Willis \& Whittaker, 2000), suggesting continued connectivity of tropical cloud forests (Ramírez-Barahona \& Eguiarte, 2013).

Previous studies have reported a reticulate genetic structure in Platanus from northern Mexico, but substantial differentiation towards the south (Nixon \& Poole, 2003; Feng et al., 2005; Grimm \& Denk, 2008). The results presented here support categorical separation without reticulate exchange between Platanus populations in Chiapas and Oaxaca, as there was little allelic connection between north and south (Veracruz-Chiapas) and west and east (Oaxaca-Chiapas). Moreover, if the Chiapas population had originated from postglacial expansion from a Oaxaca refugium, it would show a substantial loss of genetic variability, which is not the case. It is therefore suggested, in line with previous studies (Feng et al., 2005; Luna-Vega, 2008), that genetic differentiation of the Chiapas Platanus population is due to a process of vicariance which could be explained by topographic heterogeneity, especially in the upper Grijalva Basin.

According to the results of the present study, the genetic structure of Platanus mexicana var. mexicana in southern Mexico can be explained by three processes: I) Population contraction and expansion of a refugium in Oaxaca during the 
Pleistocene, with allelic exchange towards the north; II) Allopatric differentiation towards the Gulf of Mexico (Veracruz) due to natural selection; III) Vicariance towards the south of the distribution, with substantial differentiation in Chiapas.

\section{ACKNOWLEDGEMENTS}

The authors would like to thank the "Programa para el Mejoramiento del Profesorado" (PROMEP) for providing funding to perform this research project. The authors also appreciated receiving training on the principles and molecular techniques used in this work by Dr. Olga De Castro and Dr. Paolo De Luca, Department of Biology, Universitá degli Studi di Napoli Federico II, Naples, Italy.

\section{CONFLICT OF INTERESTS}

The authors declare no conflict of interests.

\section{REFERENCES}

Aide, T.M. \& E. Rivera. 1998. Geographic patterns of genetic diversity in Poulsenia armata (Moraceae): implications for the theory of Pleistocene refugia and the importance of riparian forest. Journal of Biogeography 25(4):695-705. https://doi.org/10.1046/j.1365-2699.1998.2540695.x

Avise, J. 2004. Molecular Markers, Natural History, and Evolution. Sunderland, MA, USA. Sinauer Associates, Inc.

Besnard, G., A. Tagmount, P. Baradat, A. Vigouroux \& A. Bervillé. 2002. Molecular approach of genetic affinities between wild and ornamental Platanus. Euphytica 126(3):401-412. https://doi.org/10.1023/A:1019912425987

Bornet, B. \& M. Branchard. 2001. Nonanchored inter simple sequence repeat (ISSR) markers: Reproducible and specific tools for genome fingerprinting. Plant Molecular Biology Reporter 19(3):209-215. https://doi.org/10.1007/BF02772892

Bricchi, E., G. Frenguelli \& G. Mincigrucci. 2000. Experimental results about Platanus pollen deposition. Aerobiologia 16(3-4):347-352. https://doi.org/10.1023/A:1026701028901

Chase, M. \& H. Hills. 1991. Silica gel: an ideal material for field preservation of leaf samples for DNA studies. Taxon 40(2):215-220. https://doi.org/10.2307/1222975

Colinvaux, P.A., P.E. de Oliveira \& M.B. Bush. 2000. Amazonian and neotropical plant communities on glacial time scales: The failure of the aridity and refuge hypotheses. Quaternary Science Reviews 19:141-169. https://doi.org/10.1016/S0277-3791(99)00059-1

Comes, H.P. \& J.W. Kadereit 1998. The effect of Quaternary climatic changes on plant distribution and evolution. Trends in Plant Science 3(11):432-438. https://doi.org/10.1016/S1360-1385(98)01327-2 
CONABIO. 2010. El Bosque Mesófilo de Montaña en México: Amenazas y Oportunidades para su Conservación y Manejo Sostenible. Comisión Nacional para el Conocimiento y Uso de la Biodiversidad, México. D. F.

De Castro, O., M.A. Di-Maio, J.A. Lozada-García, D. Piacenti, M. Vázquez-Torres \& P. De-Luca. 2013. Plastid DNA sequencing and Nuclear SNP genotyping help resolve the puzzle of central American Platanus. Annals of Botany 112(3):589-602. https://doi.org/10.1093/aob/mct134

Demesure, B., B. Comps \& R.J. Petit. 1996. Chloroplast DNA phylogeography of the common beech (Fagus sylvatica L.) in Europe. Evolution 50(6):2515-2520. https://doi.org/10.2307/2410719

Denk, T., G.W. Grimm \& A.K. Röseler. 2012. When field botany meets history: Taxonomy of Platanus mexicana in Mexico. Willdenowia 42(1):99-115. https://doi.org/10.3372/wi.42.42113

Doyle, J.J. \& J.L. Doyle. 1990. Isolation of plant DNA from fresh tissue. Focus 12:1315.

Edwards, S.V., S. Potter, C.J. Schmitt, J.G. Bragg \& C. Moritz. 2016. Reticulation, divergence, and the phylogeography-phylogenetics continuum. Proceedings of the National Academy of Sciences of the United States of America 113(29):8025-8032. https://doi.org/10.1073/pnas.1601066113

Esselman, E.J., D.J. Crawford, S. Brauner, T.F. Stuessy, G.J. Anderson \& O.M. Silva. 2000. RAPD marker diversity within and divergence among species of Dendroseris (Asteraceae: Lactuceae). American Journal of Botany 87(4):591-596. https://doi.org/10.2307/2656603

Evanno, G., S. Regnaut \& J. Goudet. 2005. Detecting the number of clusters of individuals using the software STRUCTURE: a simulation study. Molecular Ecology 14(8):2611-2620. https://doi.org/10.1111/j.1365-294X.2005.02553.X

Falush, D., M. Stephens \& J.K. Pritchard. 2007. Inference of population structure using multilocus genotype data: dominant markers and null alleles. Molecular Ecology Notes 7(4):574-578. https://doi.org/10.1111/j.1471-8286.2007.01758.x

Feng, Y., S.H. Oh \& P.S. Manos. 2005. Phylogeny and historical biogeography of the genus Platanus as inferred from nuclear and chloroplast DNA. Systematic Botany 30(4):786-799. https://doi.org/10.1600/036364405775097851

Foll, M. \& O. Gaggiotti. 2008. A genome-scan method to identify selected loci appropriate for both dominant and codominant markers: a Bayesian perspective. Genetics 180(2):977-993. https://doi.org/10.1534/genetics.108.092221

Galván-Hernández, D.M., J.A. Lozada-García, N. Flores-Estévez, J. GalindoGonzález S.M. Vázquez-Torres. 2015. Variation and genetic structure in Platanus mexicana (Platanaceae) along riparian altitudinal gradient. International Journal of Molecular Sciences 16(1):2066-2077. https://doi.org/10.3390/ijms16012066 
Graham, A. 1999. Late Cretaceous and Cenozoic history of North American vegetation: north of Mexico. Oxford University, USA. 370 p.

Grimm, G. \& T. Denk. 2008. ITS evolution in Platanus (Platanaceae): homoeologues, pseudogenes and ancient hybridization. Annals of Botany 101(3):403-419. https://doi.org/10.1093/aob/mcm305

Grueva, M. \& P. Zhelev 2011. Population genetic structure of Platanus orientalis L. in Bulgaria. iForest-Biogeosciences and Forestry 4(4):186. https://doi.org/10.3832/ifor0580-004

Hampe, A. \& A.S. Jump. 2011. Climate relicts: past, present, future. Annual Review of Ecology, Evolution, and Systematics 42:313-333. https://doi.org/10.1146/annurevecolsys-102710-14501

Hewitt, G.M. 2011. Quaternary phylogeography: the roots of hybrid zones. Genetica 139(5):617-638. https://doi.org/10.1007/s10709-011-9547-3

Konnert, M. \& F. Bergmann. 1995. The geographical distribution of genetic variation of silver fir (Abies alba, Pinaceae) in relation to its migration history. Plant Systematics and Evolution 196 (1-2):19-30. https://doi.org/10.1007/BF00985333

Luna-Vega, I. 2008. Aplicaciones de la biogeografía histórica a la distribución de las plantas mexicanas. Revista Mexicana de Biodiversidad 79(1):217-241. http://scielo.unam.mx/scielo.php?pid=S1870-

34532008000100018\&amp;script=sci arttex

Lynch, M. \& B.G. Milligan. 1994. Analysis of population genetic structure with RAPD markers. Molecular Ecology 3(2):91-99. https://doi.org/10.1111/j.1365294X.1994.tb00109.x

Miller, P. 1997. TFPGA (Tools for population genetic analyses), v 1.3. A Windows program for the analysis of allozyme and molecular population genetic data. Computer software distributed by the author.

Nei, M. \& W.H. Li. 1979. Mathematical model for studying genetic variation in terms of restriction endonucleases. Proceedings of the National Academy of Sciences of the United States of America 76(10):5269-5273. https://doi.org/10.1073/pnas.76.10.5269

Nixon, K.C. \& J.M. Poole. 2003. Revision of the Mexican and Guatemalan species of Platanus (Platanaceae). Lundellia 6:103-137. https://doi.org/10.25224/1097-993x$\underline{6.1 .4}$

Peakall, R. \& P.E. Smouse. 2006. GENALEX 6: genetic analysis in Excel. Population genetic software for teaching and research. Molecular Ecology Notes 6(1):288-295. https://doi.org/10.1111/j.1471-8286.2005.01155.x 
Ramírez-Barahona, S. \& L.E. Eguiarte. 2013. The role of glacial cycles in promoting genetic diversity in the Neotropics: the case of cloud forest during the last glacial maximum. Ecology and Evolution 3(3):725-738. https://doi.org/10.1002/ece3.483

Rico, Y. 2019. Landscape genetics of Mexican biodiversity: A review. Acta Universitaria 29: 1-23. https://doi.org/10.15174/au.2019.1894

Slatkin, M. \& N.H. Barton. 1989. A comparison of three indirect methods for estimating average levels of gene flow. Evolution 43(7):1349-1368. https://doi.org/10.2307/2409452

Soltis, D.E., M.A. Gitzendanner, D.D. Strenge \& P.S. Soltis. 1997. Chloroplast DNA intraspecific phylogeography of plants from the Pacific Northwest of North America. Plant Systematics and Evolution 206:353-373. https://doi.org/10.1007/BF00987957

Sosa, V., J.A. De-Nova \& M. Vásquez-Cruz. 2018. Evolutionary history of the flora of Mexico: Dry forests cradles and museums of endemism. Journal of Systematics and Evolution 56(5):523-536. https://doi.org/10.1111/jse.12416

Toledo, V. 1982. Pleistocene changes of vegetation in tropical Mexico. Proceedings of the fifth International Symposium of the Association for Tropical Biology, New York.

Trieu, L.N., N.T. Mien, T. Van Tien, N. Van Ket \& N. Van Duy. 2016. Genetic diversity of Panax stipuleanatus Tsai in North Vietnam detected by inter simple sequence repeat (ISSR) markers. Biotechnology \& Biotechnological Equipment 30(3):506-511. https://doi.org/10.1080/13102818.2016.1157448

Vovides, A.P., D. Gonzalez, M.A. Pérez-Farrera, S. Avendaño \& C. Bárcenas. 2004. A review of research on the cycad genus Ceratozamia Brongn. (Zamiaceae) in Mexico. Taxon 53(2):291-297. https://doi.org/10.2307/4135609

Wang, X., L. Li, J. Zhao, F. Li, W. Guo \& X. Chen. 2017. Effects of different preservation methods on inter simple sequence repeat (ISSR) and random amplified polymorphic DNA (RAPD) molecular markers in botanic samples. Comptes Rendus Biologies 340(4):204-213. https://doi.org/10.1016/j.crvi.2017.03.002

Willis, K. \& R. Whittaker. 2000. The refugial debate. Science 287:1406-1407. https://doi.org/10.1126/science.287.5457.1406

Xiao, L.Q. \& X. Gong. 2006. Genetic differentiation and relationships of populations in the Cycas balansae complex (Cycadaceae) and its conservation implications. Annals of Botany 97(5):807-812. https://doi.org/10.1093/aob/mcl039 